Tropical Journal of Pharmaceutical Research January 2018; 17 (1): 97-104

ISSN: $1596-5996$ (print); 1596-9827 (electronic)

(C) Pharmacotherapy Group, Faculty of Pharmacy, University of Benin, Benin City, 300001 Nigeria.

\title{
Toxicity assessment of aqueous extract of Curtisia dentata (Burm.f) C.A. Sm: stem bark in male Wistar rats
}

\author{
Olubunmi Abosede Wintola*, Anthony Jide Afolayan \\ Medicinal Plants and Economic Development (MPED) Research Centre, Department of Botany, University of Fort Hare, Alice, \\ 5700, South Africa
}

*For correspondence: Email: owintola@ufh.ac.za Tel: +27 (0)719760385

Sent for review: 13 July 2017

Revised accepted: 7 October 2017

\begin{abstract}
Purpose: To investigate the acute and sub-acute toxicity effects of aqueous stem bark extract in male Wistar rats.

Methods: For the acute toxicity study, a single dose of $5000 \mathrm{mg} / \mathrm{kg}$ body weight of the extract was orally administered to the animals by oral gavage and the rats thereafter were observed for mortality and toxicity signs for 14 days. In the sub-acute toxicity test, the graded doses $(50,100$, and $200 \mathrm{mg} / \mathrm{kg}$ body weight) of the aqueous extract of $C D$ were given to the animals once daily for 28 days. In each of the experiment, the food and water intake, body weight changes, relative organ weights, hematological, clinical biochemistry and histopathological parameters were evaluated.

Results: In both the acute and sub-acute toxicity studies, $C D$ did not show any visible signs of toxicity. There were also no significant differences $(p>0.05)$ between the control and $C D$-treated rats for all the investigated parameters; no obvious gross pathological features in the kidney, heart and liver of all the experimental animals were observed.

Conclusion: The findings indicate that the extract is not toxic when administered at the tested doses and within the exposure period. Thus, the aqueous stem bark extract of $C D$ may be adjudged relatively safe and pharmacologically non-toxic in Wistar rats.
\end{abstract}

Keywords: Curtisia dentata, Hematopoietic, Histopathology, Toxicity

\begin{abstract}
This is an Open Access article that uses a funding model which does not charge readers or their institutions for access and distributed under the terms of the Creative Commons Attribution License (http://creativecommons.org/licenses/by/4.0) and the Budapest Open Access Initiative (http://www.budapestopenaccessinitiative.org/read), which permit unrestricted use, distribution, and reproduction in any medium, provided the original work is properly credited.

Tropical Journal of Pharmaceutical Research is indexed by Science Citation Index (SciSearch), Scopus, International Pharmaceutical Abstract, Chemical Abstracts, Embase, Index Copernicus, EBSCO, African Index Medicus, JournalSeek, Journal Citation Reports/Science Edition, Directory of Open Access Journals (DOAJ), African Journal Online, Bioline International, Open-J-Gate and Pharmacy Abstracts
\end{abstract}

\section{INTRODUCTION}

Curtisia dentata is a common South African plant belonging to the family Cornaceae. It is known as "Assegaai" by the Afrikaans speaking people while the Xhosa and the Zulu people of South Africa call it "umLahleni". The plant is disseminated in the forests of KwaZulu-Natal down to the Western Cape via the Eastern Cape and up the Limpopo Provinces of South Africa
[1]. It is commonly found along the forest margins, on mountains and grassland of southern Africa. Curtisia dentata is geographically endemic to southern and eastern coasts of South Africa; extending to Zimbabwe, Mozambique and Swaziland [2,3]. Curtisia dentata is one of the most threatened plants of South Africa, as a result of the high trading of the stembark and leaves [4]. Triterpene compounds (2-a- hydroxyursolic acid and lupeol as well as 
ursolic acid and betulinic acid) have been isolated from the plant, and these have shown great pharmacological importance [1,3]. The antimicrobial properties of these isolated compounds have been reported [3]. Previous reports indicated that the plant is potent against some pathogenic microbes and free living nematodes [3].The stem bark of CD has also been shown to possess antimicrobial activity and relieving stomach ailments and diarrhea. Its significant therapeutic effects in sexually transmitted infections, as purgative, blood purifier and aphrodisiac have been reported [5-7]. The stem bark infusion extract of $C$. dentata has found relevance in livestock for the management of the dreaded heartwater disease of cattle in South Africa [8] and also, it is used in the treatment of pimples in humans, $[8,9]$. Other pharmacological significance of the stem bark extracts of CD as antioxidant, anti-hyperlipidemic and cytotoxic agent have also been documented $[3,10,11]$.

In spite of the increasing number of reports on the medicinal benefits of CD stem bark, the in vivo toxicological implications of treatment with its extracts is yet to be elucidated. It is on this background, therefore, that the present study was conceptualized to investigate the acute and sub-acute toxicity of the stem bark aqueous extract of CD in a Wistar rat model. This study is envisaged to provide significant baseline information for further studies on developing this plant as a viable herbal medicine.

\section{EXPERIMENTAL}

\section{Plant material collection, identification and sample extraction}

Mature stem barks of Curtisia dentata were collected between May and June, 2016 at Ntselamanzi area, Eastern Cape Province, South Africa. The plant was authenticated by Prof DS Grierson, a taxonomist at University of Fort Hare, Alice, South Africa. A voucher specimen was formally prepared and deposited at Giffen's herbarium (no. Win 2014/2). The mature stembark was washed with copious amounts of distilled water to remove dirt and subsequently oven-dried $\left(40^{\circ} \mathrm{C}\right)$ for one week. The stem barks were turned daily to allow for uniform drying. After drying, the sample was pulverised and extracted in sterile distilled water and agitated in a, shaker (Orbital Incubator Shaker, Gallenkamp) for $24 \mathrm{~h}$. The infusion obtained was filtered (Whatman No. 1 filter paper) and the resulting filtrate was freeze-dried (Vir Tis benchtop K, Vir Tis Co., Gardiner, NY) at $-40{ }^{\circ} \mathrm{C}$. The crude extract (CDE) obtained was kept air-tight and refrigerated prior to use.

\section{Experimental animals}

Thirty-six (36) male Wistar rats weighing $100.0 \pm$ $14.5 \mathrm{~g}$ were obtained from the central animal unit of the University of Fort Hare, South Africa. The rats were housed in clean polypropylene cages in a well-ventilated room. They were fed ad libitum with rat pellets and tap water freed of contaminants. The animals were allowed to acclimatize for 7 days before the start of the experiment. The rats were maintained at $22 \pm 2$ ${ }^{\circ} \mathrm{C}$ on a light/dark cycle for $12 \mathrm{~h}$ and $40-45 \%$ relative humidity. The cages were cleaned on a daily basis and treatments were in accordance with the guidelines of the Ethics Committee on the use and care of Experimental Animals of the University of Fort Hare, Alice, South Africa. The research also adhered strictly to the Principles contained in the United State National Institutes of Health Laboratory Animal Care $(\mathrm{NIH}$ Publication, No. 85-23) [12]. The study was approved by the institutional ethical committee 'of the University of Fort Hare (no. UFH-REC270710-028-RA WIN001) prior to commencement of the study.

\section{Acute toxicity study}

This was carried out according to the Organization for Economic Co-operation and Development (OECD) guidelines number 420 [13]. Prior to dosing with the extract, the rats were fasted overnight but allowed free access to water. A single dose of $5000 \mathrm{mg} / \mathrm{kg}$ body weight (b.w.) of CDE was orally administered to 6 rats and designated as the treatment group. The rats in the control group $(n=6)$ were given sterile distilled water. All the experimental animals were maintained under close observation for any signs of toxicity and mortality immediately after dosing. They were also observed individually during the first $30 \mathrm{~min}$ and $4 \mathrm{~h}$ post-dosing period and thereafter $24 \mathrm{~h}$ for a period of 14 days. On the $15^{\text {th }}$ day, all rats were anaesthetized using halothane and blood samples were collected via cardiac puncture into heparinized and EDTAcontaining bottles and subsequently used for biochemical and hematological analysis, respectively using BS-200 Automatic Biochemistry Analyzer (Mindary Co., Ltd) and Automated Hematology System Analyzer (Archem BM240, Turkey). The animals were thereafter humanely sacrificed by cervical dislocation, dissected and the liver, kidney and heart were removed. The organs were cleaned with saline, weighed and preserved in 10\% buffered formalin for histopathological 
examination [14]. The relative organ weight (ROW) of each organ for each animal was also calculated.

\section{Sub-acute toxicity test}

The sub-acute toxicity testing was conducted according to OECD guidelines 407 for testing plant extracts [15]. The 24 rats used were randomized into four groups of 6 rats each. Animals in groups 1-3 were, respectively, administered $1 \mathrm{~mL}$ each of CDE at 50,100 and $200 \mathrm{mg} / \mathrm{kg}$ day, while group 4 was given $1 \mathrm{~mL}$ distilled water and served as control. The administrations were done only once daily via oral intubation and lasted for 28 days. Probable signs of toxicity, morbidity, and mortality were monitored throughout the investigation period. The feed and water intakes were monitored daily and the average calculated at every 4-day interval, while their body weights were measured at the initial and on weekly basis throughout the period of 28 days [16]. At the end of the experiment, all the rats were anesthetized using halothane and blood samples were similarly collected and processed as detailed in the acute toxicity study. Following this, the rats were humanely sacrificed by cervical dislocation, dissected and the organs harvested and processed as earlier highlighted.

\section{Data analysis}

Data are expressed as mean \pm standard error of mean (SEM, $\mathrm{n}=6$ ) and were subjected to oneway analysis of variance (ANOVA) followed by Duncan multiple range test to determine significant difference for all the parameters. Values were considered statistically significant at $p<0.05$.

\section{RESULTS}

There were no signs of toxicity or mortality observed in both the acute and sub-acute toxicity testing in this study. The cage side observation revealed that all the animals were essentially normal in healthy condition, maintained normal behaviors and usual movement patterns throughout the investigation periods. There were no significant $(p>0.05)$ differences in both the body weight changes and the ROW between the control and CDE-administered rats (Table 1 and Table 2).

Similarly, the histopathological examination of the investigated organs did not show any differences in their histoarchitectural features when compared with the control in both the acute

Table 1: Weight gain and relative organ weights (g/100 g body weight) of rats administered $5000 \mathrm{mg} / \mathrm{kg} \mathrm{b} . \mathrm{w}$. Curtisia dentata stem bark aqueous extract

\begin{tabular}{lcccccccc}
\hline Parameter & $\begin{array}{c}\text { Initial body } \\
\text { weight } \mathbf{( g )}\end{array}$ & $\begin{array}{c}\text { Final body } \\
\text { weight } \mathbf{( g )}\end{array}$ & $\begin{array}{c}\text { Weight of } \\
\text { liver } \mathbf{( g )}\end{array}$ & $\begin{array}{c}\text { Weight } \\
\text { of kidney } \\
\mathbf{( g )}\end{array}$ & $\begin{array}{c}\text { Weight } \\
\text { of heart } \\
\text { (g) }\end{array}$ & $\begin{array}{c}\text { Relative } \\
\text { liver } \\
\text { weight }\end{array}$ & $\begin{array}{c}\text { Relative } \\
\text { kidney } \\
\text { weight }\end{array}$ & $\begin{array}{c}\text { Relativ } \\
\text { heart } \\
\text { weight }\end{array}$ \\
\hline $\begin{array}{l}5000 \mathrm{mg} / \mathrm{kg} \\
\text { extract dose }\end{array}$ & $231.44 \pm 3.76$ & $308.52 \pm 2.74$ & $8.69 \pm 0.30$ & $1.90 \pm 0.54$ & $1.12 \pm 0.04$ & $2.82 \pm 0.05$ & $0.62 \pm 0.18$ & $0.36 \pm 0.02$ \\
$\begin{array}{l}\text { Control } \\
\text { (distilled } \\
\text { water) }\end{array}$ & $135.33 \pm 2.72$ & $214.2 \pm 2.03$ & $8.53 \pm 0.99$ & $1.94 \pm 0.14$ & $1.06 \pm 0.06$ & $2.90 \pm 0.30$ & $0.66 \pm 0.05$ & $0.36 \pm 0.02$ \\
\hline
\end{tabular}

Mean \pm SEM. Values without superscripts in the same column for each parameter are not significantly different $(p>0.05)$

Table 2: Weight gain and relative organ weights of rats administered Curtisia dentata aqueous extract for 28 days

\begin{tabular}{lllll}
\hline Parameter & $\mathbf{5 0 ~} \mathbf{~ m g / k g}$ & $\mathbf{1 0 0} \mathbf{~ m g / k g}$ & $\mathbf{2 0 0} \mathbf{~ m g / k g}$ & $\begin{array}{c}\text { Control (distilled } \\
\text { water) }\end{array}$ \\
\hline Initial body weight (g) & $95.77 \pm 5.74$ & $94.58 \pm 4.27$ & $86.00 \pm 8.50$ & $94.12 \pm 1.42$ \\
Final body weight (g) & $252.32 \pm 4.05$ & $251.00 \pm 25.86$ & $246.71 \pm 14.88$ & $253.10 \pm 10.21$ \\
Weight of liver (g) & $10.01 \pm 1.79$ & $9.07 \pm 1.56$ & $9.13 \pm 0.52$ & $9.11 \pm 0.45$ \\
Weight of kidney (g) & $2.22 \pm 0.04$ & $2.27 \pm 0.27$ & $2.25 \pm 0.01$ & $2.22 \pm 0.07$ \\
Weight of heart (g) & $1.01 \pm 0.08$ & $0.94 \pm 0.07$ & $1.04 \pm 0.05$ & $0.96 \pm 0.05$ \\
Liver body weight (\%) & $3.61 \pm 0.67$ & $3.60 \pm 0.35$ & $3.65 \pm 0.04$ & $3.64 \pm 0.10$ \\
Kidney body weight (\%) & $0.83 \pm 0.03$ & $0.83 \pm 0.06$ & $0.78 \pm 0.04$ & $0.78 \pm 0.21$ \\
Heart body weight (\%) & $0.36 \pm 0.01$ & $0.38 \pm 0.02$ & $0.36 \pm 0.01$ & $0.35 \pm 0.13$ \\
\hline
\end{tabular}

Mean \pm SEM. Values without superscripts in the same row for each parameter are not significantly different $(p>0.05)$ 
(i) Kidney

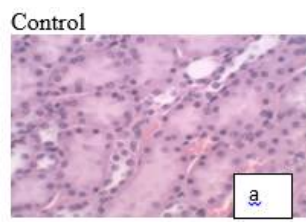

Control

(ii) Liver

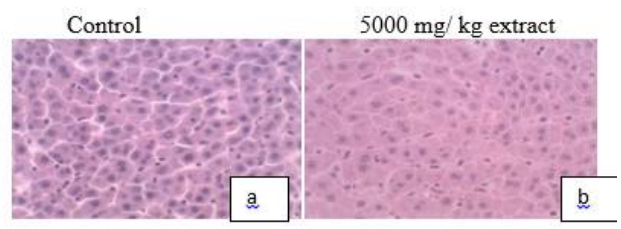

Control

$5000 \mathrm{mg} / \mathrm{kg}$ extract

(iii) Heart

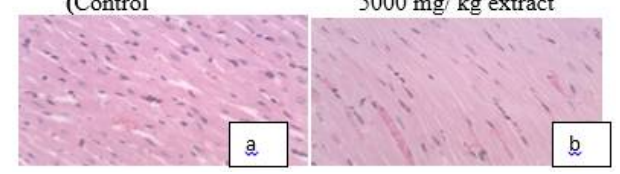

Figure 1: Photomicrographs (400x, Hematoxylin + eosin stained) of tissue sections of the (i) kidney, (ii) liver and (iii) heart of control (a) and (b) $5000 \mathrm{mg} / \mathrm{kg}$ body weight aqueous stem bark extract of $C$. dentata treated male rats for 14 days showing well preserved histoarchitectural features of the respective organs

and sub-acute toxicity studies (Figure 1 and Figure 2). In the acute toxicity testing, the liver showed normal architecture, clear lumen of central vein and no evidence of lesion; the kidney showed adequate glomeruli and normal tubules, with no traces of focal intestinal edema and lesion; the heart showed normal architecture of the myocardium (Figure 1). Similar observations were noticed in the sub-acute toxicity study where the liver, kidney and heart of the CDEtreated rats did not show any differences when compared with the control (Figure 2). The data obtained with respect to the amount of food and water consumed also showed no statistical significant $(p>0.05)$ differences between the CDE-treated animals and the control rats in the sub-acute toxicity testing (Figure 3 and Figure 4).
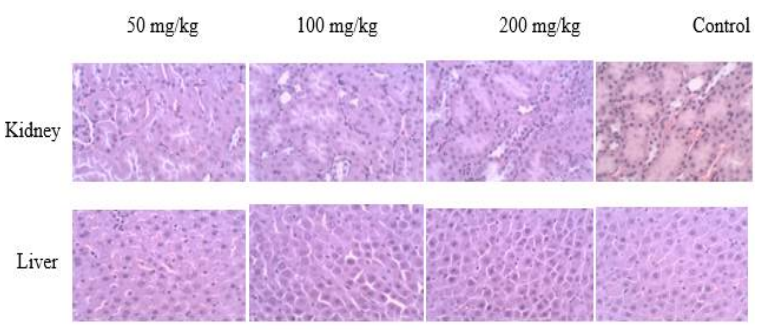

Heart

Figure 2: Photomicrographs (400x, Hematoxylin + eosin stained) from the kidney, liver and heart of the 28-day CDE-treated rats and control. There are no treatment-related microscopic changes in all the organs CDE-administered rats compared to the control rats

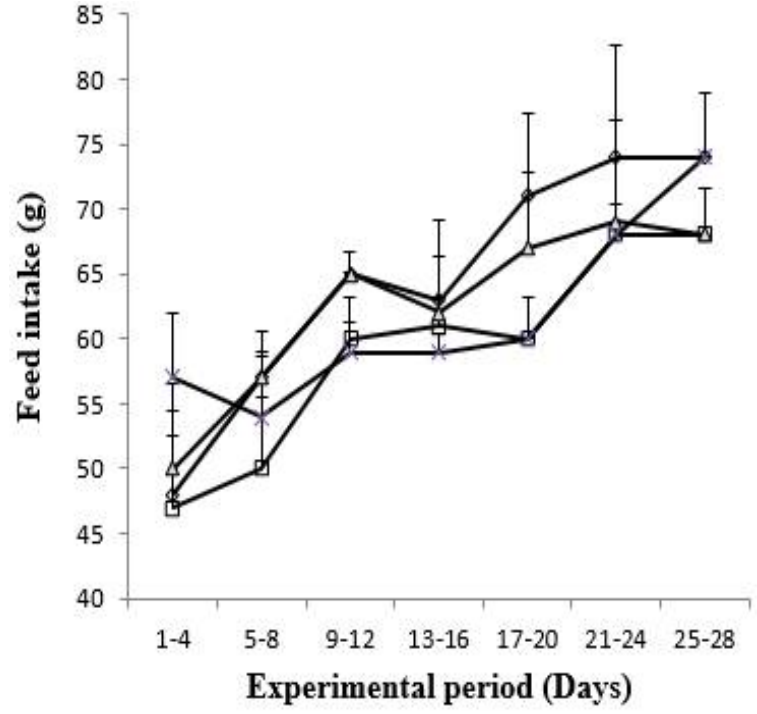

Figure 3: Effect of aqueous stem bark extract of $C$. dentata on feed intake of the animals over 28 days; 50 $\mathrm{mg} / \mathrm{kg}(\diamond), 100 \mathrm{mg} / \mathrm{kg}(\square), 200 \mathrm{mg} / \mathrm{kg}(\Delta)$ and control $(x)$

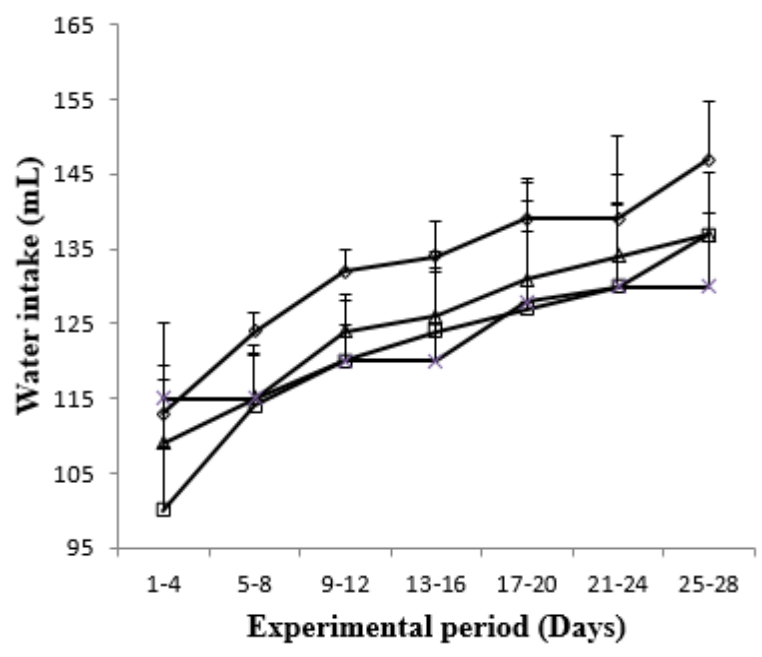

Figure 4: Effect of aqueous stem bark extract of $C$. dentata on water intake of the animals over 28 days; $50 \mathrm{mg} / \mathrm{kg}(\diamond), 100 \mathrm{mg} / \mathrm{kg}(\square), 200 \mathrm{mg} / \mathrm{kg}(\Delta)$ and control $(x)$

Table 3 to Table 6 show the results of the hematological and clinical biochemistry parameters of the control and extract-treated animals in both the acute and sub-acute toxicity studies, respectively. There were no significant $(p>0.05)$ differences in these parameters for the $\mathrm{CDE}$-administered rats and the respective control in the two experimental protocols.

\section{DISCUSSION}

Phytomedicine has become universally acceptable in primary health care, particularly in developing countries like South Africa. Although, medicinal plants are presumed to be safe without 
Table 3: Effect of a single dose $(5000 \mathrm{mg} / \mathrm{kg}$ body weight) administration of stem bark aqueous extract of Curtisia dentata on haematological parameters of male Wistar rats

\begin{tabular}{|c|c|c|}
\hline Parameter & $\begin{array}{c}5000 \\
\mathrm{mg} / \mathrm{kg} \\
\text { extract }\end{array}$ & $\begin{array}{c}\text { Control } \\
\text { (distilled water) }\end{array}$ \\
\hline Hemoglobin (g/dL) & $16.15 \pm 0.35$ & $16.45 \pm 0.35$ \\
\hline Haematocrit (L/L) & $0.55 \pm 0.02$ & $0.54 \pm 0.00$ \\
\hline $\begin{array}{l}\text { Mean corpuscular } \\
\text { volume(fl) }\end{array}$ & $64.65 \pm 1.65$ & $61.5 \pm 2.12$ \\
\hline $\begin{array}{l}\text { Mean corpuscular } \\
\text { hemoglobin }(\mathrm{pg})\end{array}$ & $18.85 \pm 0.15$ & $18.80 \pm 0.00$ \\
\hline $\mathrm{MCHC}(\mathrm{g} / \mathrm{dL})$ & $32.2 \pm 0.50$ & $33.00 \pm 1.41$ \\
\hline $\begin{array}{l}\text { Red blood cell } \\
\text { distribution width (\%) }\end{array}$ & $11.1 \pm 0.20$ & $11.5 \pm 0.99$ \\
\hline $\begin{array}{l}\text { Red blood cell } \\
\left(10^{12} / \mathrm{L}\right)\end{array}$ & $8.54 \pm 0.11$ & $8.48 \pm 0.30$ \\
\hline Platelets $\left(10^{y} / \mathrm{L}\right)$ & $778 \pm 2.69$ & $769 \pm 2.43$ \\
\hline $\begin{array}{l}\text { White blood cell } \\
\left(10^{9} / \mathrm{L}\right)\end{array}$ & $9.15 \pm 1.05$ & $9.08 \pm 1.56$ \\
\hline Neutrophils $\left(10^{y} / \mathrm{L}\right)$ & $0.44 \pm 0.10$ & $0.44 \pm 0.09$ \\
\hline Monocytes $\left(10^{y} / \mathrm{L}\right)$ & $2.03 \pm 0.40$ & $2.08 \pm 0.01$ \\
\hline Eosinophils $\left(10^{y} / \mathrm{L}\right)$ & $0.15 \pm 0.20$ & $0.18 \pm 0.01$ \\
\hline Lymphocytes $\left(10^{9} / \mathrm{L}\right)$ & $4.61 \pm 1.25$ & $4.51 \pm 1.62$ \\
\hline \multicolumn{3}{|c|}{$\begin{array}{l}\text { Data are mean } \pm S E M \text {. Values without superscripts in } \\
\text { the same row for each parameter are not significantly } \\
\text { different }(p>0.05) \text {. MCHC }=\text { mean corpuscular } \\
\text { haemoglobin concentration }\end{array}$} \\
\hline
\end{tabular}

Table 4: Effect of a single dose $(5000 \mathrm{mg} / \mathrm{kg}$ body weight) administration of stem bark aqueous extract of Curtisia dentata on biochemical parameters of male Wistar rats

\begin{tabular}{|c|c|c|}
\hline Parameter & $\begin{array}{c}5000 \mathrm{mg} / \mathrm{kg} \\
\text { extract }\end{array}$ & Control \\
\hline Sodium (mmol/L) & $140.50 \pm 1.29$ & $140.25 \pm 1.89$ \\
\hline Chloride (mmol/L) & $104.00 \pm 2.16$ & $104 \pm 0.82$ \\
\hline Calcium (mmol/L) & $2.37 \pm 0.03$ & $2.39 \pm 0.03$ \\
\hline $\begin{array}{l}\text { Magnesium } \\
(\mathrm{mmol} / \mathrm{L})\end{array}$ & $1.00 \pm 0.02$ & $1.10 \pm 0.10$ \\
\hline Uric acid (mmol/L) & $0.09 \pm 0.01$ & $0.11 \pm 0.01$ \\
\hline Urea $(\mathrm{mmol} / \mathrm{L})$ & $4.23 \pm 0.40$ & $4.13 \pm 0.30$ \\
\hline Creatinine (umol/L) & $40.25 \pm 5.44$ & $41.25 \pm 5.56$ \\
\hline Total protein $(\mathrm{g} / \mathrm{L})$ & $52.25 \pm 2.06$ & $51.00 \pm 1.83$ \\
\hline Albumin $(g / L)$ & $18.25 \pm 0.50$ & $17.50 \pm 0.58$ \\
\hline $\begin{array}{l}\text { Total bilirubin } \\
\text { (umol/L) }\end{array}$ & $9.00 \pm 1.15$ & $9.25 \pm 2.06$ \\
\hline $\begin{array}{l}\text { Conjugated bilirubin } \\
\text { (umol/L) }\end{array}$ & $3.50 \pm 1.29$ & $3.50 \pm 0.96$ \\
\hline $\begin{array}{l}\text { Alkaline } \\
\text { phosphatase }(\mu / L)\end{array}$ & $180.50 \pm 1.31$ & $183.33 \pm 1.01$ \\
\hline $\begin{array}{l}\text { Alanine } \\
\text { aminotransferase } \\
(\mu / L)\end{array}$ & $50.50 \pm 1.24$ & $52.00 \pm 1.83$ \\
\hline $\begin{array}{l}\text { Aspartate } \\
\text { aminotransferase } \\
(\mu / L)\end{array}$ & $168.00 \pm 3.57$ & $167.50 \pm 3.66$ \\
\hline
\end{tabular}

any compromising health effects Oladipupo et al [17], evaluation of their toxicological implications on key metabolic markers of animals and humans is imperative. Such evaluation will form a crucial part of their assessment for potential toxic effects. To the best of our knowledge, this is the first study reporting the safety profiles of CDE in vivo. In the acute toxicity study, a limit dose of $5000 \mathrm{mg} / \mathrm{kg}$ of CDE elicited neither signs of toxicity nor mortality during the 14 days observation period. This observation may indicate that its oral median lethal dose $\left(\mathrm{LD}_{50}\right)$ value is greater than $5000 \mathrm{mg} / \mathrm{kgb} . \mathrm{w}$. and could suggest that the extract is non-acutely toxic when orally administered in Wistar rats.

Furthermore, the treatment with a single limit dose of CDE also had no significant (deleterious) effect on the hematological, clinical biochemistry, histopathological and ROW parameters of the experimental rats. This is another probable reason buttressing the non-acute toxic effect of CDE. These observations are in agreement with earlier reports of Sabiu and Ashafa [18] and Afolayan et al [19]. The authors demonstrated the non-acute toxic potential of some crude plant extract on Wistar rats.

Consequent upon the no treatment-perturbed toxicological effects of CDE in the oral acute toxicity study, the 28-days repeated dosing evaluation was performed to provide detailed toxicological data on CDE. In this study, the repeated graded dosing (50, 100, and 200 $\mathrm{mg} / \mathrm{kg}$ ) of the animals with the extract also had no clinical signs of toxicity and recorded neither morbidity nor mortality across all the treatment groups and could suggest that CDE is not likely to be toxic at these regimens and within the exposure period.

Changes in the body weight of animals could provide vital clue on their well-being and also constitute an important index in toxicological studies [20]. The proportionately increased body weight in both experimental protocols for the controls and the CDE-treated animals in this study could indicate that treatment with the extract had no consequential effect on their normal metabolic processes relating to growth and development. Similarly, the utilization of food and water by the treated animals followed a normal metabolic pattern as elicited by the animals in the control group.

This observation is not only a pointer to the nontoxic tendency of the extract but may also suggests that administration of CDE enhanced normal metabolism of the rats and did not retard their growth as evidently shown in this study. 
Table 5: Effect of 28 days administration of stem bark aqueous extract of Curtisia dentata on the haematological parameters of male Wistar rats

\begin{tabular}{lcccc}
\hline Parameter & \multicolumn{3}{c}{ Dose } \\
\cline { 2 - 5 } & $\mathbf{5 0 ~} \mathbf{~ g} / \mathbf{k g}$ & $\mathbf{1 0 0} \mathbf{~} \mathbf{g} / \mathbf{k g}$ & $\mathbf{2 0 0} \mathbf{~} \mathbf{g} / \mathbf{k g}$ & Control \\
\hline Hemoglobin $(\mathrm{g} / \mathrm{dL})$ & $14.50 \pm 0.20$ & $14.80 \pm 0.25$ & $14.60 \pm 0.56$ & $14.83 \pm 0.42$ \\
Haematocrit $(\mathrm{L} / \mathrm{L})$ & $0.49 \pm 0.02$ & $0.51 \pm 0.02$ & $0.50 \pm 0.02$ & $0.51 \pm 0.02$ \\
Mean corpuscular volume $(\mathrm{fl})$ & $61.20 \pm 0.31$ & $60.0 \pm 0.87$ & $60.2 \pm 0.82$ & $62.68 \pm 1.04$ \\
Mean corpuscular hemoglobin $(\mathrm{pg})$ & $19.50 \pm 0.20$ & $20.13 \pm 0.31$ & $19.60 \pm 0.1$ & $19.25 \pm 0.37$ \\
MCHC (g/dL) & $28.57 \pm 0.15$ & $28.87 \pm 0.15$ & $28.73 \pm 0.40$ & $29.06 \pm 0.28$ \\
Red blood cell distribution width $(\%)$ & $11.97 \pm 0.03$ & $12.07 \pm 0.62$ & $12.05 \pm 0.36$ & $11.98 \pm 0.15$ \\
Red blood cell $\left(10^{12} / \mathrm{L}\right)$ & $7.05 \pm 0.03$ & $7.03 \pm 0.25$ & $7.08 \pm 0.32$ & $7.02 \pm 0.34$ \\
Platelet $\left(10^{y} / \mathrm{L}\right)$ & $759 \pm 2.00$ & $759 \pm 1.39$ & $761.30 \pm 3.18$ & $758.67 \pm 3.19$ \\
White blood cell $\left(10^{y} / \mathrm{L}\right)$ & $5.82 \pm 0.01$ & $5.95 \pm 0.63$ & $5.85 \pm 0.59$ & $5.74 \pm 0.91$ \\
Neutrophils $\left(10^{y} / \mathrm{L}\right)$ & $0.56 \pm 0.02$ & $0.54 \pm 0.07$ & $0.52 \pm 0.61$ & $0.54 \pm 0.13$ \\
Monocytes $\left(10^{y} / \mathrm{L}\right)$ & $1.23 \pm 0.03$ & $1.23 \pm 0.02$ & $1.22 \pm 0.23$ & $1.09 \pm 0.15$ \\
Eosinophils $\left(10^{y} / \mathrm{L}\right)$ & $0.07 \pm 0.02$ & $0.07 \pm 0.02$ & $0.07 \pm 0.04$ & $0.07 \pm 0.02$ \\
Basophils $\left(10^{y} / \mathrm{L}\right)$ & $0.03 \pm 0.12$ & $0.02 \pm 0.01$ & $0.02 \pm 0.01$ & $0.03 \pm 0.01$ \\
Lymphocytes & $2.53 \pm 0.03$ & $2.56 \pm 0.37$ & $2.54 \pm 0.48$ & $2.52 \pm 1.11$ \\
\hline
\end{tabular}

Data are mean \pm SEM. Values without superscripts in the same row for each parameter are not significantly different $(p>0.05) . M C H C=$ mean corpuscular haemoglobin concentration

Table 6: Effect of 28 days administration of stem bark aqueous extract of Curtisia dentata on biochemical parameters of male Wistar rats

\begin{tabular}{lcccc}
\hline Parameter & \multicolumn{3}{c}{ Dose } \\
\cline { 2 - 5 } & $\mathbf{5 0} \mathbf{~} \mathbf{g} / \mathbf{k g}$ & $\mathbf{1 0 0} \mathbf{~} \mathbf{g} / \mathbf{k g}$ & $\mathbf{2 0 0} \mathbf{~} \mathbf{g} / \mathbf{k g}$ & Control \\
\hline Sodium $(\mathrm{mmol} / \mathrm{L})$ & $143.00 \pm 2.00$ & $145.67 \pm 8.50$ & $145.70 \pm 0.88$ & $147.80 \pm 0.84$ \\
Magnesium (mmol/L) & $1.35 \pm 0.20$ & $1.38 \pm 0.05$ & $1.38 \pm 0.05$ & $1.38 \pm 0.07$ \\
Calcium (mmol/L) & $2.47 \pm 0.21$ & $2.47 \pm 0.02$ & $2.40 \pm 0.67$ & $2.47 \pm 0.01$ \\
Potassium $(\mathrm{mmol} / \mathrm{L})$ & $3.73 \pm 0.21$ & $3.77 \pm 0.67$ & $3.79 \pm 0.35$ & $3.77 \pm 0.25$ \\
Chloride $(\mathrm{mmol} / \mathrm{L})$ & $103.07 \pm 3.51$ & $99.00 \pm 2.65$ & $99.01 \pm 1.00$ & $103.09 \pm 1.22$ \\
Uric acid & $0.20 \pm 0.02$ & $0.23 \pm 0.05$ & $0.25 \pm 0.21$ & $0.23 \pm 0.01$ \\
Total protein $(\mathrm{g} / \mathrm{L})$ & $55.33 \pm 1.15$ & $53.67 \pm 2.04$ & $55.70 \pm 2.08$ & $52.20 \pm 2.05$ \\
Albumin $(\mathrm{g} / \mathrm{L})$ & $19.33 \pm 0.58$ & $19.30 \pm 0.58$ & $19.30 \pm 0.58$ & $19.83 \pm 0.45$ \\
Total bilirubin (umol/L) & $14.87 \pm 1.53$ & $14.83 \pm 1.04$ & $14.90 \pm 1.61$ & $14.80 \pm 1.15$ \\
Conjugated bilirubin $(u m o l / L)$ & $7.03 \pm 0.58$ & $6.97 \pm 1.40$ & $7.00 \pm 1.00$ & $7.00 \pm 1.00$ \\
Alkaline phosphatase $(\mu / \mathrm{L})$ & $308.00 \pm 1.00$ & $305.33 \pm 1.45$ & $304.70 \pm 1.28$ & $305.04 \pm 1.00$ \\
Alanine aminotransferase $(\mu / \mathrm{L})$ & $66.00 \pm 2.31$ & $69.67 \pm 1.03$ & $65.00 \pm 1.42$ & $65.08 \pm 1.63$ \\
Aspartate aminotransferase $(\mu / \mathrm{L})$ & $328.67 \pm 1.06$ & $323.67 \pm 1.53$ & $324.09 \pm 1.76$ & $324.06 \pm 2.89$ \\
\hline Data are mean \pm SEM Values without superscripts in the same row for each parameter are not significantly \\
different $(p>0.05)$
\end{tabular}

ROW is more viable and sensitive index of toxicity than absolute organ weight as it relates the overall wellbeing of the animals to each of their organ [21]. The non-significant changes in the ROW of the CDE-administered animals relative to the control rats in both the acute and sub-acute toxicity studies are indicative of the well preserved functionality of the investigated organs. These were further supported by the non-toxic infiltrations of the extract on the overall histoarchitectural features of the kidney, heart and liver of the treated rats as shown in this study.

The haematological and clinical biochemistry parameters investigated in this study are useful indices to ascertain the safety profiles of plant extracts in metabolically active experimental animals [16]. The non-significant differences in the hematological indices for the control rats and the extract-treated animals in the acute toxicity test following the 28-days repeated dosing treatment with CDE could be suggestive of its non-toxic effect on the hematopoietic system. Specifically, the non-significant effect on the hemoglobin $(\mathrm{Hb})$, red blood cell $(\mathrm{RBC})$ counts and their related parameters (heamatocrit, red blood cell distribution width, mean corpuscular hemoglobin and mean corpuscular hemoglobin concentra-tion) may indicate that, the morphology as well as either incorporation of $\mathrm{Hb}$ into the RBCs or osmotic fragility of the RBCs was not affected subsequent to CDE administration. It could also imply that treatment with CDE both acutely and in the 28-days repeated daily dosing did not predispose the rats to anaemic condition within the evaluation period.

These findings corroborate previous reports $[18,19]$, where similar assertions were made while evaluating the toxicological implications of treatment with plant extracts on the blood 
systems of Wistar rats. The unaltered white blood cell (WBC) and platelet counts subsequent to treatment with CDE may also be a further probable reason that the vascular permeability and immune system of the treated rats were adequately maintained and corroborated the non-haematotoxic effect of the CDE at the investigated doses and within the period of experimentation.

The kidney and liver function parameters are important biomarkers and any damage to these organs has often been associated with alteration in their serum concentrations [22,23]. Therefore, the non-significant effects observed in all the renal and liver function indices investigated in this study following treatment with CDE for 28 days at the tested doses is a further confirmation of its non-toxic effect. Hence, it could be logically inferred that the extract is unlikely to be toxic to the liver and the kidney at the tested doses and within the exposure period as evidently supported by the photomicrographs of the investigated organs.

\section{CONCLUSION}

$\mathrm{CDE}$ has been established to have a $\mathrm{LD}_{50}$ value $>5000 \mathrm{mg} / \mathrm{kg}$ in rats. Although, further studies to determine the long-term toxicity effects of CDE in animals is imperative to establish its complete safety profile. The aqueous stem bark extract can be considered relatively safe at the tested doses and over the period of exposure used in this study.

\section{DECLARATIONS}

\section{Acknowledgement}

The authors greatly appreciate the National Research Foundation (NRF) (Grant No. T304) and Govan Mbeki Research and Development Centre (GMRDC) of the University of Fort Hare, South Africa (Grant no. C275) for financing this study.

\section{Conflict of interest}

No conflict of interest is associated with this study.

\section{Contribution of Authors}

The authors declare that this work was done by the authors named in this article and all liabilities pertaining to claims relating to the content of this article will be borne by them. OAW and AJA conceived and design the study, OAW prepared the extracts and carried out the study. AJA helped in the coordination and revise of the manuscript. All authors read and approved the final manuscript.

\section{REFERENCES}

1. Shai LJ, McGaw LJ, Aderogba MA, Mdee LK, Eloff JN. Four pentacyclic triterpenoids with antifungal and antibacterial activity from Curtisia dentata (Burm.f) C.A. Sm. leaves. J Ethnopharmacol 2008; 119: 238-244.

2. Yembaturova $E Y$, Van Wyk B-E, Tinley PM. A review of the genus Curtisia (Curtisiaceae). Bothalia 2009; 39: 8796.

3. Fadipe VO, Mongalo NI, Opoku AR. In vitro evaluation of the comprehensive antimicrobial and antioxidant properties of Curtisia dentata (Burm.f) C.A. Sm: toxicological effect on the Human embryonic kidney (HEK293) and Human hepatocellular carcinoma (HepG2) cell lines. Exp Clin J EXCLI J 2015; 14: 971983.

4. Ndawonde BG. Medicinal plant sales: A case study in Northern Zululand. MSC Dissertation. University of Zululand, South Africa. 2006.

5. Cunningham $A B$. An investigation of the herbal medicine trade in Natal/KwaZulu. Investigational report no 29. Institute of Natural Resources. University of Natal. Pietermaritzburg. 1988.

6. Hutchings $A$, Scott $A H$, Lewis G, Cunningham $A B$. Zulu medicinal plants: An inventory. University of Natal Press; 1996, pp 226-227.

7. McGaw LJ, Jager AK, van Staden J. Antibacterial, anthelmintic and anti-amoebic activity in South African medicinal plants. J Ethnopharmacol 2000; 72: 247-263.

8. Dold AP, Cocks ML. Traditional veterinary medicine in the Alice district of the Eastern Cape Province, South Africa. South Afr J Sci 2001; 97: 375-379.

9. Shai LJ, McGaw LJ, Eloff JN. Extracts of the leaves and twigs of the threatened tree Curtisia dentata Cornaceae are more active against Candida albicans and other microorganisms than the stem bark extract. South Afr $J$ Bot 2009a; 75: 363-366.

10. Doughari JH, Ndakidemi PA, Human IS, Benade S. Antioxidant, antimicrobial and antiverotoxic potentials of extracts of Curtisia dentata. J Ethnopharmacol 2012; 141: 1041-1050.

11. Oyedemi SO, Oyedemi BO, Arowosegbe S, Afolayan AJ. Phytochemicals Analysis and Medicinal Potentials of Hydroalcoholic Extract from Curtisia dentata (Burm.f) C.A. Sm Stem Bark. Int J Mol Sci 2012; 13: 6189-6203.

12. National Institute of Health. Guide for the care and use of laboratory animals. NIH publication no. 85-23, Bethesda, USA, 1985.

13. Organization of Economic Co-Operation and Development (OECD), "Guideline for testing of chemicals, acute oral toxicity-acute toxicity class method". Tech. Rep. 423; 2001. 
14. Drury RAB, Wallington EA. Carleton's Histological Techniques 5th edition. Oxford University Press, 1980; 36-148

15. Organization of Economic Co-Operation and Development (OECD) Repeated dose oral toxicity test method. In: OECD Guidelines for testing of chemicals, $N^{\circ}$ 407. Organization for Economic Cooperation and Development, Paris, France; 2008

16. Sabiu S, Sunmonu TO, Ajani EO, Ajiboye, TO. Combined administration of silymarin and vitamin $C$ stalls acetaminophen-mediated hepatic oxidative insults in Wistar rats. Rev Brasil Farmacog 2015; 25: 29-34.

17. Oladipupo AE, Sabiu S, Bamishaye FA. Four weeks daily dose oral administration assessment of Cyperus esculentus $L$. aqueous extract on key metabolic markers of Wistar rats. Pharmacologia 2016; 7: 125-133.

18. Sabiu S, Ashafa AOT. Evaluation of daily double dose administration of ethanolic root extract of Morella serrata (Lam.) Killick in rats. J Exp Integr Med 2016; 6(3): 109117.
19. Afolayan AJ, Wintola OA, Fouche G. Acute and Subacute Toxicological Evaluation of the Aerial Extract of Monsonia angustifolia E. Mey. ex. A. Rich in Wistar Rats. Evidence-Based Complement and Altern Med2016; 8 pages, Article ID 4952485.

20. Sireatawong S, Lertprasertsuke N, Srisawat U. Acute and sub-chronic toxicity study of the water extract from Tiliacora trianora (Colebr.) Diels in rats. Songklankarin J Sci Tech 2008; 30(6): 729-737.

21. Demma J, Gebre-Mariam T, Asres K, Evgetie W, Engindawork E. Toxicology study on Glinus lotoides: a traditionally used technical herb in Ethiopia, J Ethnopharmacol 2006; 111: 451-457.

22. Sunmonu TO, Oloyede OB. Nephrotoxicity of crude oil contaminated catfish (Clarias gariepinus) on albino rats. Nig J Biochem Mol Biol 2006; 26(1): 25-34.

23. Ajani EO, Sabiu S, Bamisaye FA, Ibrahim S, Salau BA. Evaluation of the acute and sub-acute toxicity effect of ethanolic leaves extract of Lagenaria brevifolia (Bitter gourd) on hepatic and renal function of rats. $J$ Pharm Biol Sci 2014; 9: 61-68. 